\title{
Research Article \\ Dye-Sensitized Solar Cells (DSSCs) Based on Extracted Natural Dyes
}

\author{
Ahmed M. Ammar ${ }^{D},{ }^{1}$ Hemdan S. H. Mohamed, ${ }^{1,2}$ Moataz M. K. Yousef, ${ }^{1}$ \\ Ghada M. Abdel-Hafez, ${ }^{3}$ Ahmed S. Hassanien, ${ }^{1}$ and Ahmed S. G. Khalil ${ }^{1}{ }^{1}$ \\ ${ }^{1}$ Physics Department, Environmental and Smart Technology Group (ESTG), Faculty of Science, Fayoum University, \\ Fayoum 63514, Egypt \\ ${ }^{2}$ State Key Laboratory of Advanced Technology for Materials Synthesis and Processing, Wuhan University of Technology, \\ 122 Luoshi Road, 430070 Wuhan, Hubei, China \\ ${ }^{3}$ Chemistry Department, Faculty of Science, Fayoum University, Fayoum 63514, Egypt
}

Correspondence should be addressed to Ahmed S. G. Khalil; asg05@fayoum.edu.eg

Received 20 October 2018; Accepted 25 February 2019; Published 18 April 2019

Academic Editor: Hiromasa Nishikiori

Copyright (c) 2019 Ahmed M. Ammar et al. This is an open access article distributed under the Creative Commons Attribution License, which permits unrestricted use, distribution, and reproduction in any medium, provided the original work is properly cited.

\begin{abstract}
Here, three natural dyes were extracted from different fruits and leaves and used as sensitizers for dye-sensitized solar cells (DSSCs). Chlorophyll was extracted from spinach leaves using acetone as a solvent. Anthocyanin was extracted from red cabbage and onion peels using water. Different characterizations for the prepared natural dyes were conducted including UV-vis absorption, FTIR, and steady-state/time-resolved photoluminescence spectroscopy. Various DSSCs based on the extracted dyes were fabricated. The degradation in the power conversion efficiencies was monitored over a week. The effect of the $\mathrm{TiO}_{2}$ mesoporous layers on the efficiency was also studied. The interfaces between the natural dyes and the $\mathrm{TiO}_{2}$ layers were investigated using electrochemical impedance spectroscopy.
\end{abstract}

\section{Introduction}

Over the last years, various types of solar cells have been developed to convert sunlight to electricity. Crystalline, polycrystalline, and amorphous silicon solar cells have been widely used for different domestic and industrial application [1-3]. Multijunction semiconductor solar cells have shown the world record efficiency of $46 \%$ [4]. However, their applications are mostly limited to space industry. There are other types of less efficient and low-cost cells, such as dyesensitized solar cells (DSSCs) [5] and organic solar cells [6]. These cells have been around for years and stimulated useful studies; however, their implementation for large-scale applications is still limited.

DSSC was firstly reported by O'Regan and Grätzel in 1991 [5]. The highest power conversion efficiency (PCE) reported for DSSCs using ruthenium complex dyes (N719) was $11-12 \%[7,8]$. One of the main challenges of DSSCs is the long-term stability. Electrolyte leakage, dye desorption, and degradation of the dye itself are considered the most important parameters affecting the cell stability $[9,10]$.

Researchers have been focusing on the modification of each component of the DSSC with the aim to improve the PCE. For instance, in order to obtain more effective nanostructured semiconductor photoanodes, different shapes have been utilized such as nanoparticles, nanorods, nanotubes, nanosheets, and mesoporous structure [11-15]. Ruthenium and osmium metal-organic complexes have been the most stable and effective dyes used for DSSCs $[16,17]$. Due to the fact that these dyes are toxic, expensive, and difficult to synthesize, growing activities for using natural dyes have been reported [18-20]. Natural-based DSSCs have not shown high efficiency compared to the artificial ones, mainly due to the weak binding with $\mathrm{TiO}_{2}$ 
film as well as the low charge-transfer absorption in the whole visible range [21]. However, many reports have been recently published on using extracted natural dyes from natural products and tested for DSSCs [22-31]. Karakuş et al. employed Pelargonium hortorum and Pelargonium grandiflorum as sensitizers in their DSSCs and achieved a PCE of $0.065 \%$ and $0.067 \%$, respectively [32]. Ramanarayanan et al. extracted the dye from the leaves of red amaranth and studied the effect of using different solvents, such as water and ethanol, and achieved PCE of $0.230 \%$ and $0.530 \%$, respectively [33]. Hosseinnezhad et al. extracted the dye from Sambucus ebulus and PCE of 1.15\% was reported [34]. Despite the fact that all these studies showed low PCE compared to other conventional cells, still the mechanism of operation and performance are of great interest, mainly to explore new insights and understanding for these sophisticated cells.

In this work, different dyes were extracted from red cabbage, onion peels, and spinach and used as sensitizers for the DSSCs. The optical and structural properties of the dyes and the fabricated cells were studied. Furthermore, the interface between the dye and $\mathrm{TiO}_{2}$ was investigated by impedance spectroscopy. The degradation in the PCE of N719 and natural-based DSSCs was monitored.

\section{Experimental}

2.1. Materials. Onion peels, red cabbage, and spinach leaves used in this study were collected from Fayoum City, Egypt. $\mathrm{HCl}$ and acetic acid were purchased from Loba Chemie. Isopropanol was purchased from Fisher Scientific. FTO conductive glass (sheet resistance: $7 \Omega / s q$ ), P25 $\mathrm{TiO}_{2}$ nanopowder, titanium isopropoxide, $\alpha$-terpineol, ethyl cellulose, and di-tetrabutylammonium cis-bis(isothiocyanato)bis $\left(2,2^{\prime}\right.$ -bipyridyl-4,4' -dicarboxylato)ruthenium(II) - (N719 dye)were purchased from Sigma-Aldrich. Iodolyte was purchased from Solaronix.

2.2. Extraction of the Natural Dyes. Water was used as the extraction solvent for onion peels and red cabbage. $6 \mathrm{gm}$ of onion peel and $147 \mathrm{gm}$ of chopped red cabbage were dispersed into $250 \mathrm{ml}$ and $400 \mathrm{ml}$ of distilled water, respectively. The dispersions were heated up at $90^{\circ} \mathrm{C}$ for 24 hours. After cooling down to room temperature, the dispersions were filtered through filter papers to extract the anthocyanin (dye) for use as sensitizers. A third dye was extracted from spinach using acetone as the extraction solvent. $11 \mathrm{gm}$ of spinach was crushed into fine powder using a mortar and dispersed in acetone. The solution was then filtered, and the resulting filtrate was used as natural sensitizer. All dye solutions were stored in the dark.

2.3. DSSC Fabrication. FTO conductive glass substrates were firstly cleaned in labosol solution for $30 \mathrm{~min}$ followed by rinsing in water-ethanol solution of $\mathrm{NaOH}$ for another $30 \mathrm{~min}$. $\mathrm{TiO}_{2}$ blocking layer was prepared by adding $2.4 \mathrm{ml}$ of titanium isopropoxide to $34 \mathrm{ml}$ of isopropanol into a plastic bottle with stirring. Then, $0.8 \mathrm{ml}$ of $2 \mathrm{M} \mathrm{HCl}$ was added dropwise and the solution left under stirring for 24 hours. The coating solution was spread on the surface by using spin coater ( $1000 \mathrm{rpm}$ for $10 \mathrm{~s}$ followed by $3000 \mathrm{rpm}$ for $60 \mathrm{~s}$ ). The formed layer was sintered at $120^{\circ} \mathrm{C}$ for $120 \mathrm{~min}$. $\mathrm{TiO}_{2}$ mesoporous layer was prepared by adding $1.5 \mathrm{gm}$ of titania with $6 \mathrm{ml}$ of terpineol-ethyl cellulose mixture. $0.25 \mathrm{ml}$ of acetic acid was slowly added to the mixture with continuous grinding for $15 \mathrm{~min}$. Then, $6 \mathrm{ml}$ of isopropanol was added with grinding for $15 \mathrm{~min}$ until it gets homogenous. The paste was deposited on the FTO conductive glass by doctor-blading technique to obtain a $\mathrm{TiO}_{2}$ mesoporous with a thickness of $15 \mu \mathrm{m}$ and an area of $1 \mathrm{~cm}^{2}$. The layer was preheated at $120^{\circ} \mathrm{C}$ for $150 \mathrm{~min}$ then sintered at $460^{\circ} \mathrm{C}$ for $15 \mathrm{~min}$. After cooling to $80^{\circ} \mathrm{C}$, the $\mathrm{TiO}_{2}$ electrode was immersed in dye solutions for $24 \mathrm{~h}$. The iodide/triiodide $\left(\mathrm{I}-/ \mathrm{I}_{3}{ }^{-}\right)$was used as the electrolyte solution. DSSC was assembled by filling the electrolyte between a $\mathrm{TiO}_{2}$ electrode (anode) and a conductive glass substrate plated with $\mathrm{Pt}$ (cathode).

2.4. Characterizations. The UV-vis absorption was recorded using Agilent Cary 60 spectrometer. The Fourier transmission infrared (FTIR) spectra were recorded using Mattson Satellite IR to analyze the functional groups of the natural dyes. The steady-state photoluminescence spectroscopy was carried out using AVANTUS Ava-florescence setup featured with AvaSpec-ULS2048L-USB2 detector with the following specifications: back-thinned CCD (charged coupled device) image sensor array of 2048 pixels, symmetrical CzernyTurner monochromator (600 line/mm), 200-1160 nm of wavelength scanning range, $25 \mu \mathrm{m}$ slit, DCL-UV/VIS-200 detector collection lens, AvaLight-LED355, $450 \mathrm{~nm}$ light sources, and two FCR-UV200/600-2-IND fiber optics. Time-resolved PL measurements were performed using a time correlated single photon counting device (PicoQuant "PicoHarp-300"). A pulsed diode laser head at different repetition rates was used to excite the sample at $440 \mathrm{~nm}$ controlled by (PicoQuant PDL 800-D pulsed driver controller). The pulse duration of the laser was about 200 ps. The PL from the sample was filtered using long pass filters from $520 \mathrm{~nm}$ to pick up only band edge emission. The emitted photons were focused onto a fast avalanche photodiode (MPD-100-CTB, SPAD, Micro Photon Device). The response time of the photodiode was $<50$ ps. The excitation photon flux was controlled using neutral filters with different optical density.

The surface morphology of the $\mathrm{TiO}_{2}$ films was characterized by scanning electron microscope (Carl ZEISS Gemini, Sigma $500 \mathrm{VP})$. The photocurrent-voltage $(I-V)$ characteristics were performed using Keithley 2450 under sunlight. SMP smart pyranometer (Kipp \& Zonen, Netherlands) was used to measure the reference input irradiation. A Voltalab PGZ 100 potentiostat/galvanostat system was used to perform the electrochemical impedance spectroscopic measurements. All potentiodynamic polarization experiments were carried out using a constant scan rate of $10 \mathrm{mV} \mathrm{s}^{-1}$. The impedance measurements were recorded in the frequency domain 0.1$10^{5} \mathrm{~Hz}$, with a superimposed ac-signal of $10 \mathrm{mV}$ peak to peak. Each experiment was carried out at least twice to be sure that the results are reproducible. 


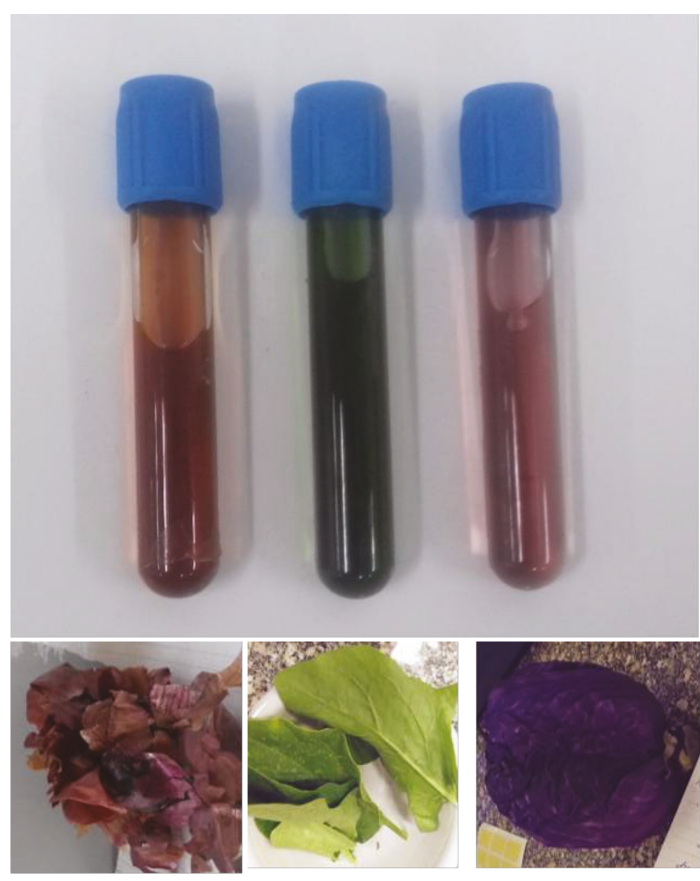

(a)

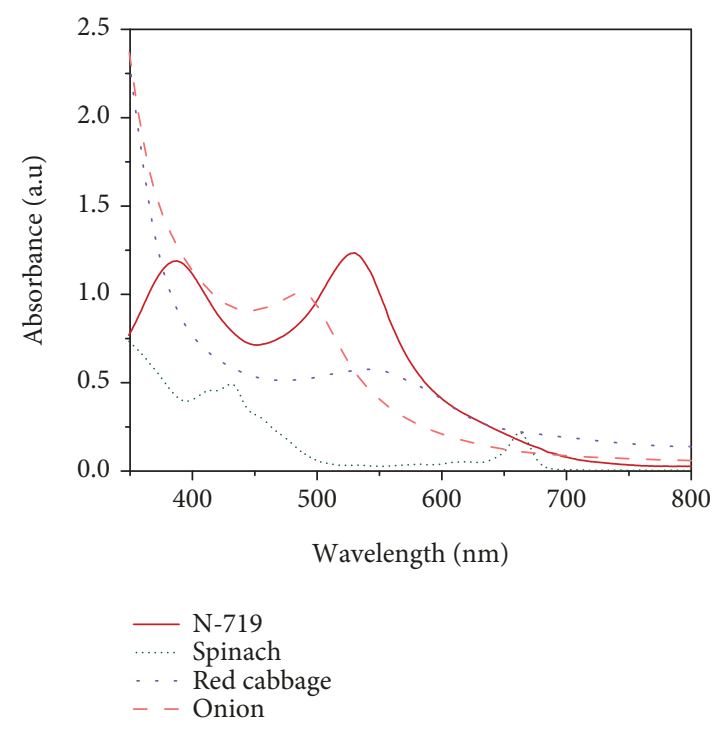

(b)

Figure 1: (a) Optical images of the extracted dyes from onion peels, spinach, and red cabbage. (b) UV-vis absorption spectra of the extracted natural dyes and N719.

\section{Results and Discussion}

Figure 1 displays the optical images of the extracted natural dyes from onion peels, spinach, and red cabbage and their representative UV-vis absorption. The UV-vis absorption of N719 was also shown for the sake of comparison. It can be noticed that N719 have two wide absorption peaks at $387 \mathrm{~nm}$ and $530 \mathrm{~nm}$. These peaks have been previously reported [35]. For the anthocyanin extracted from red cabbage and onion peels, absorption peaks at $544 \mathrm{~nm}$ and $486 \mathrm{~nm}$ have been shown, respectively. The absorption of the chlorophyll extracted from spinach shows two different peaks at $662 \mathrm{~nm}$ and $431 \mathrm{~nm}$. The shifts in the absorption peaks are mainly due to the different chemical structure of these dyes.

Figure 2(a) shows the schematic diagram of the main structure of DSSC prepared in this work. The detailed preparation conditions were described in Section 2. It should be emphasized here that the PCE is very sensitive to every single preparation step. Our reported results were repeated several times to make sure about the effect of the varied parameters on the PCE. Figure 2(b) presents SEM micrograph of $\mathrm{TiO}_{2}$ mesoporous layer formed on the FTO-coated glass. It can be seen that the $\mathrm{TiO}_{2}$ particles were aggregated to form homogenous and crack-free nanoclusters. Similar morphology was reported in [36]. The morphology of the photoanode strongly affects the photoelectrochemical activity of the DSSCs. The effect of $\mathrm{TiO}_{2}$ concentration in the mesoporous layer on the absorption is shown in Figure 2(c). Layers with different $\mathrm{TiO}_{2}$ concentrations $(4 \%, 6 \%, 8 \%$, and $10 \%$ ) were formed and the representative UV-vis absorption was recorded. $10 \% \mathrm{TiO}_{2}$ mesoporous layer resulted the highest possible absorption.

Different DSSCs were prepared using $\mathrm{TiO}_{2}$ mesoporous layers with different concentrations and N719 as a sensitizer. The $J-V$ characteristics of these cells are shown in Figure 3(a). The overall efficiency $(\eta)$ was calculated using the following equations:

$$
\begin{aligned}
\mathrm{FF} & =\frac{V_{\mathrm{m}} J_{\mathrm{m}}}{V_{\mathrm{oc}} J_{\mathrm{sc}}}, \\
\eta & =\frac{V_{\mathrm{oc}} \cdot J_{\mathrm{sc}} \cdot \mathrm{FF}}{P_{\mathrm{in}}} \times 100 \%,
\end{aligned}
$$

where $P_{\text {in }}$ is the radiation power incident on the cell, $J_{\mathrm{sc}}$ is short-circuit current density at zero voltage, $V_{\mathrm{oc}}$ is the open-circuit voltage at zero current density, $J_{\mathrm{m}}$ is the maximum current density, $V_{\mathrm{m}}$ is maximum voltage, and $\mathrm{FF}$ is the fill factor. The resulted values are summarized in Table 1. It is clearly shown that the efficiency increases with increasing the concentration of $\mathrm{TiO}_{2}$. The short-circuit 


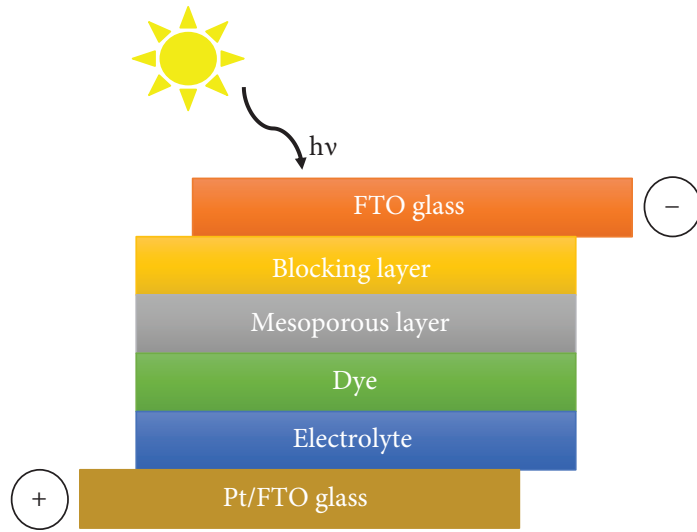

(a)

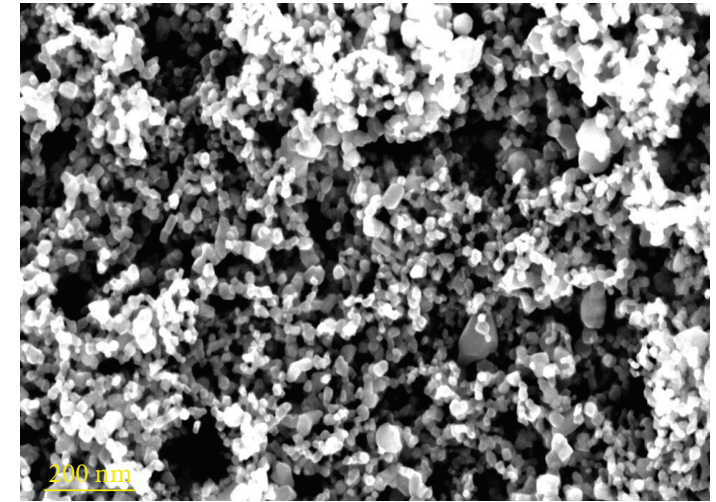

(b)
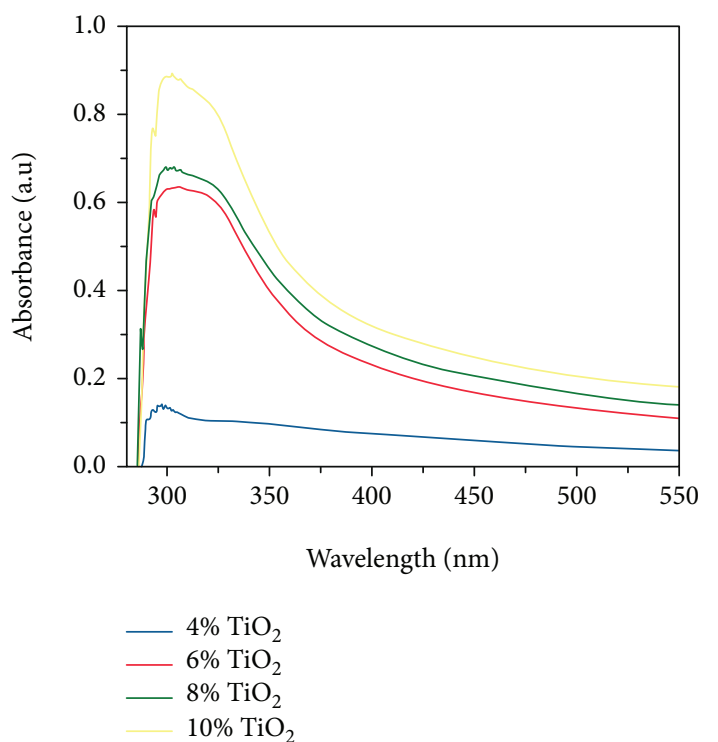

(c)

FIgURE 2: (a) A schematic description of DSSC. (b) SEM micrograph of $10 \% \mathrm{TiO}_{2}$ mesoporous layer. (c) UV-vis absorption spectra of different $\mathrm{TiO}_{2}$ mesoporous layers.

current and open-circuit voltage of $10 \% \mathrm{TiO}_{2}$ were much greater than the other concentrations. The $10 \% \mathrm{TiO}_{2}$ concentration is the threshold of the mesoporous layer, where it gives the highest possible efficiency (2.23\%). The efficiency of $10 \% \mathrm{TiO}_{2}$ cell is comparable to what has been previously reported [37].

Figure $3(\mathrm{~b})$ shows the efficiency of the $10 \% \mathrm{TiO}_{2}$ DSSC over a week. The power conversion efficiencies were $2.2 \%$, $1.88 \%, 1.68 \%$, and $1.15 \%$ for days $1,2,3$, and 7 , respectively (Table 2). $J_{\text {sc }}$ was rapidly decreased even after the first day. After a week, about 50\% degradation in the efficiency was observed. The deterioration of the PV performance is mainly due to leakage or solvent evaporation of the liquid electrolyte [38]. As soon as the cell is exposed to the air and sunlight, the electrolyte becomes unstable by producing iodate [39]. After a week, it was noted that the electrolyte evaporated. When extra amount of the electrolyte was readded, the efficiency recovered its initial values (SI 1-3). It was also reported that the degradation of the solar cell performance is due to the detachment of the dye from the $\mathrm{TiO}_{2}$ surface [40]. In our experiments, we found out that the amount of dyes adsorbed is very close to each other $\left(1.09 \times 10^{-8} \mathrm{~mol} / \mathrm{cm}^{2}-1.16 \times 10\right.$ ${ }^{-8} \mathrm{~mol} / \mathrm{cm}^{2}$ ). However, due to the different type of interactions, N719 has showed the highest possible efficiency under the used experimental conditions. The detachment can be noticed by significant rising of the internal resistance of the cell (will be discussed in the EIS section).

FTIR studies were done to confirm the chemical structure of the extracted dyes. The natural dyes need to own specific functional groups in order to effectively adsorb on the $\mathrm{TiO}_{2}$ layers [41]. As shown in Figure 4, the chlorophyll dye extracted from spinach shows a peak at $3435 \mathrm{~cm}^{-1}$ due to the presence of the hydroxyl group. The peaks at $2923 \mathrm{~cm}^{-1}$ and $2854 \mathrm{~cm}^{-1}$ correspond to $\mathrm{C}-\mathrm{H}$ stretching vibrations confirming the presence of aromatic $\mathrm{C}-\mathrm{H}$ group. $\mathrm{C}=\mathrm{O}$ stretching vibrations shows a peak at $1643 \mathrm{~cm}^{-1}$. The peak at $1056 \mathrm{~cm}^{-1}$ is attributed to the $\mathrm{C}-\mathrm{O}-\mathrm{C}$ stretching vibrations of acid and carbohydrate groups. $\mathrm{C}-\mathrm{N}-\mathrm{C}$ bending vibrations demonstrate a peak at $1385 \mathrm{~cm}^{-1}$. As observed from the functional groups of anthocyanin dye extracted from onion and red 


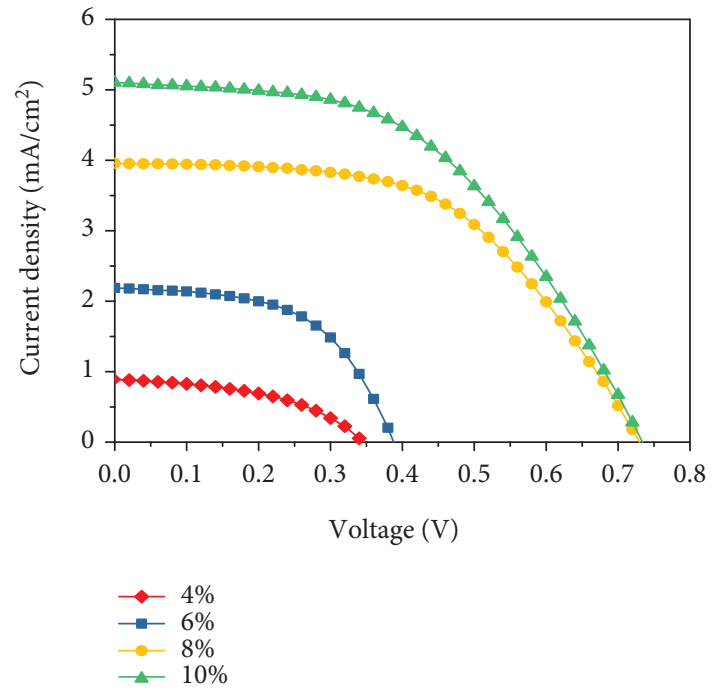

(a)

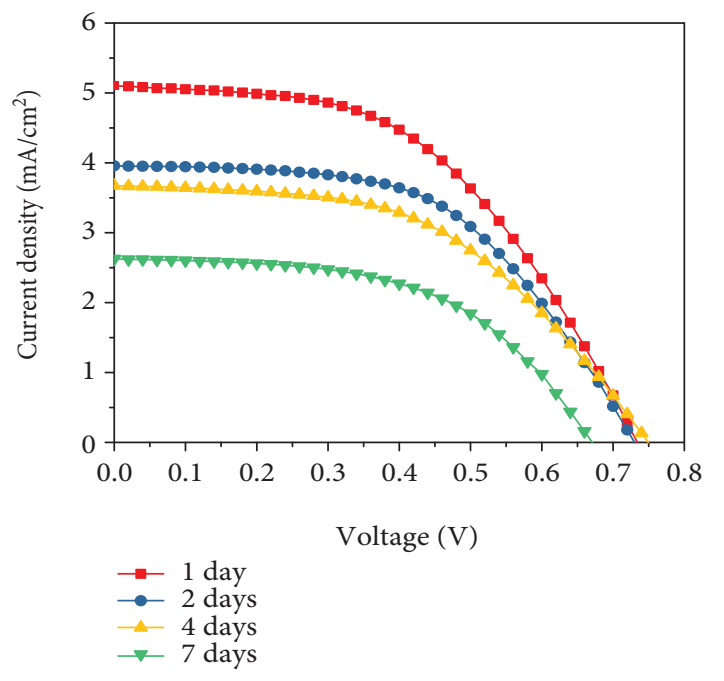

(b)

Figure 3: (a) $J$ - $V$ curves of DSSCs with different $\mathrm{TiO}_{2}$ concentrations. (b) $J-V$ curves of $10 \% \mathrm{TiO}_{2}$ DSSCs monitored for a week.

TABle 1: Photoelectrochemical parameters of DSSCs using different $\mathrm{TiO}_{2}$ concentrations.

\begin{tabular}{lcccccc}
\hline $\mathrm{TiO}_{2}$ wt $(\%)$ & $J_{\mathrm{sc}}\left(\mathrm{mA} \cdot \mathrm{cm}^{-2}\right)$ & $J_{\mathrm{m}}\left(\mathrm{mA} \cdot \mathrm{cm}^{-2}\right)$ & $V_{\mathrm{oc}}(\mathrm{V})$ & $V_{\mathrm{m}}(\mathrm{V})$ & $\mathrm{FF}(\%)$ & \multicolumn{1}{c}{$\eta(\%)$} \\
\hline $4 \%$ & 0.89 & 0.583 & 0.34 & 0.24 & 0.168578 \\
$6 \%$ & 2.91 & 1.77 & 0.39 & 0.26 & 40.54983 \\
$8 \%$ & 3.96 & 2.16 & 0.73 & 0.46 & 34.37111 \\
$10 \%$ & 5.1 & 4.04 & 0.73 & 0.46 & 49.91673 & 1.197108 \\
\hline
\end{tabular}

TABLE 2: Photoelectrochemical parameters of DSSCs over a week.

\begin{tabular}{lcccccc}
\hline Days & $J_{\mathrm{sc}}\left(\mathrm{mA} \cdot \mathrm{cm}^{-2}\right)$ & $J_{\mathrm{m}}\left(\mathrm{mA} \cdot \mathrm{cm}^{-2}\right)$ & $V_{\mathrm{oc}}(\mathrm{V})$ & $V_{\mathrm{m}}(\mathrm{V})$ & $\mathrm{FF}(\%)$ & \multicolumn{1}{c}{$\eta(\%)$} \\
\hline 1 & 5.1 & 4.04 & 0.73 & 0.46 & 0.48 & 54.10092 \\
2 & 3.95 & 3.25 & 0.73 & 0.48 & 50.57221 & 1.879518 \\
3 & 3.67 & 2.9 & 0.75 & 0.46 & 54.0378 & 1.677108 \\
7 & 2.63 & 2.07 & 0.67 & 1.147229 \\
\hline
\end{tabular}

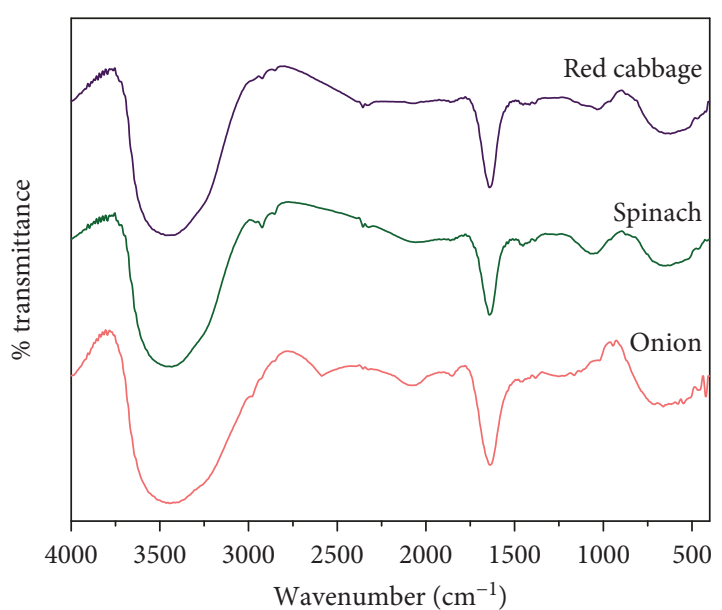

FIGURE 4: FTIR spectra of the extracted natural dyes. cabbage in Figure 3, the $\mathrm{OH}$ group among molecules indicates peaks at $3444 \mathrm{~cm}^{-1}$ and $3467 \mathrm{~cm}^{-1}$, respectively.

$\mathrm{C}=\mathrm{O}$ stretching vibration shows a peak at $1639 \mathrm{~cm}^{-1}$. Stretching vibrations of $\mathrm{C}-\mathrm{O}-\mathrm{C}$ esters demonstrate peaks at $1037 \mathrm{~cm}^{-1}$ and $1033 \mathrm{~cm}^{-1}$, respectively. These functional groups confirm the presence of chlorophyll and anthocya$\operatorname{nin}[42]$.

Figure 5(a) represents the steady-state photoluminescence of the extracted dyes measured in parallel configuration of Aventus setup. The data was collected after $10 \mathrm{~ms}$ of acquisition time (in case of onion and red cabbage) and $1 \mathrm{~ms}$ for spinach. All data was averaged over 10 times of measurements. The spectra were fitted and normalized according to Gaussian distribution.

All extracted dyes exhibited a spectral shift from UV to visible region. For anthocyanin dye, it showed an emission peak at $565 \mathrm{~nm}$, which is red-shifted by $15 \mathrm{~nm}$ compared to 


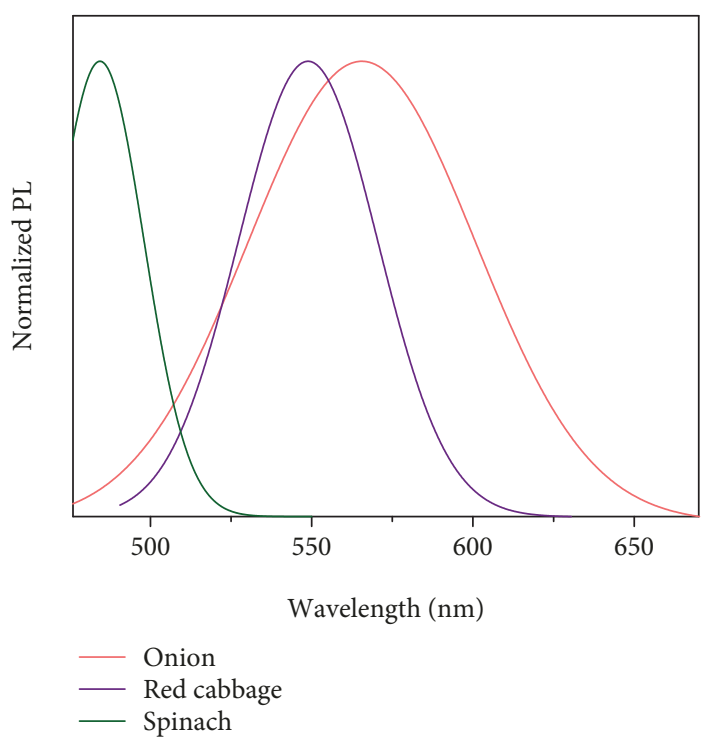

(a)

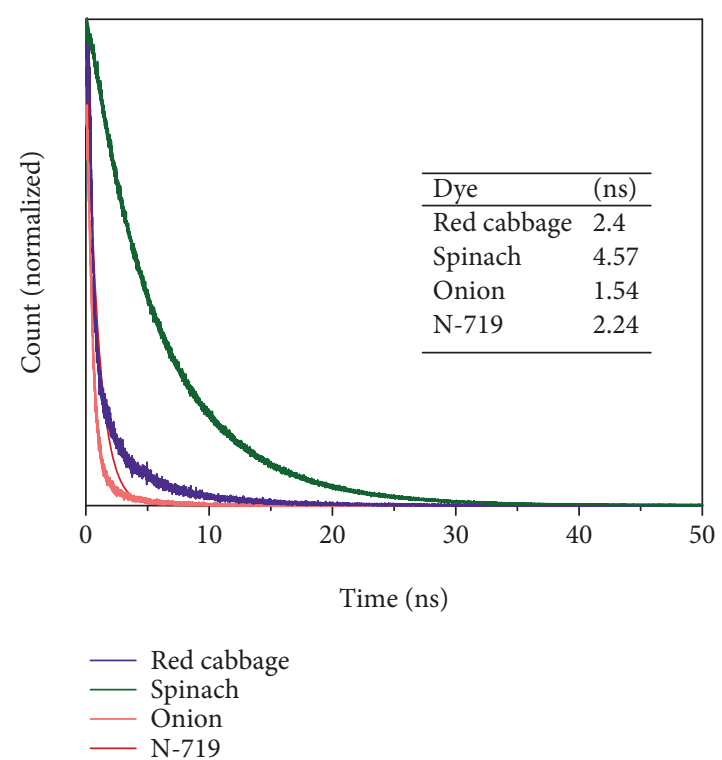

(b)

FIGURE 5: Photoluminescence spectroscopy of the extracted dyes. (a) Steady-state. (b) Time-resolved.

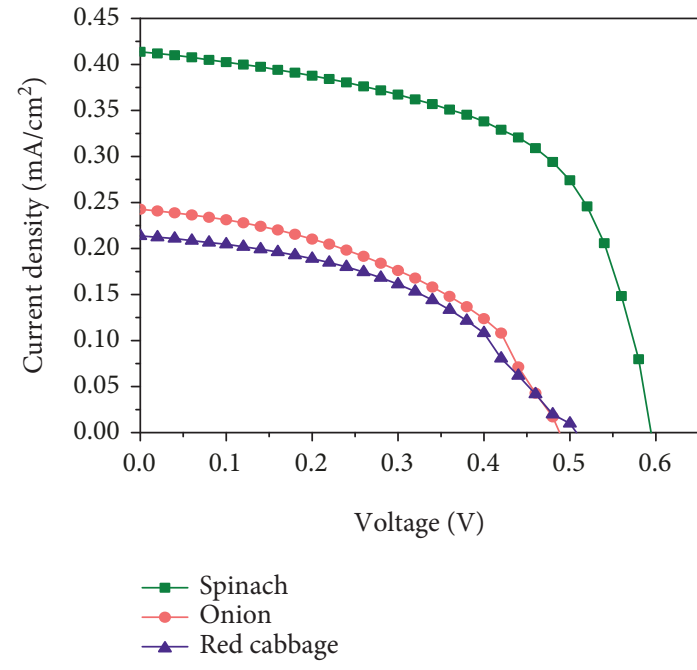

(a)

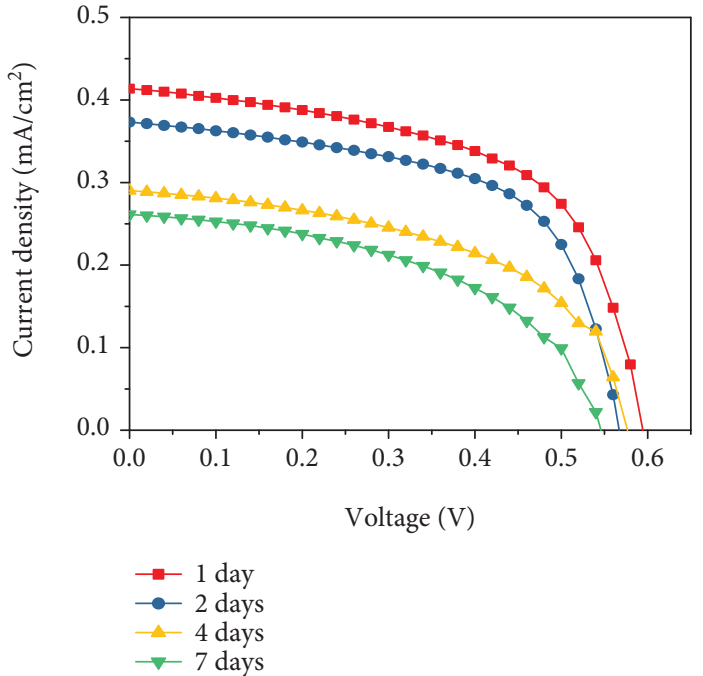

(b)

Figure 6: (a) $J-V$ curves of DSSCs using different natural dyes. (b) $J$ - $V$ curves for a solar cell sensitized with spinach extract for a week.

the extracted dye from red cabbage. On the other hand, the spinach dye emits at $485 \mathrm{~nm}$ which in prominent for an efficient photoexcitation process between absorption and emission.

The behavior of photoexcitation process in the three dyes was investigated with time-resolved photoluminescence (TRPL) as shown in Figure 5(b). It demonstrates a long lifetime for chlorophyll dye relative to anthocyanin dyes. Consequently, higher efficiency for chlorophyll-based solar cells compared to anthocyanin ones was observed.

$J-V$ characteristic curves of DSSCs based on natural dyes are given in Figure 6(a). Chlorophyll-based cells showed a high short-circuit current of $0.41 \mathrm{~mA} / \mathrm{cm}^{2}$ when compared to $0.24 \mathrm{~mA} / \mathrm{cm}^{2}$ and $0.21 \mathrm{~mA} / \mathrm{cm}^{2}$ for onion- and red cabbage-based cells, respectively (Table 3 ). The open-circuit voltage $\left(V_{\text {oc }}\right)$ of spinach, onion, and red cabbage was $0.59 \mathrm{~V}, 0.48 \mathrm{~V}$, and $0.51 \mathrm{~V}$, respectively. Furthermore, the degradation of DSSC based on spinach extract was investigated as shown in Figure 6(b). The photoelectric conversion efficiency of DSSC decreased from $0.17 \%$ to $0.08 \%$. It can be observed that the PCE of natural dye-based cells is low compared to the ones based on N719. This is attributed to the poor interaction between the natural dyes with the semiconductor electrode, restricting the transport of electrons from the excited dye molecule to the $\mathrm{TiO}_{2}$ layers [43]. The extraction process of anthocyanin from plants is nonselective 
TABLE 3: Photoelectrochemical parameters of the DSSCs with natural extracts.

\begin{tabular}{lccccrr}
\hline Dye & $J_{\mathrm{sc}}\left(\mathrm{mA} \cdot \mathrm{cm}^{-2}\right)$ & $J_{\mathrm{m}}\left(\mathrm{mA} \cdot \mathrm{cm}^{-2}\right)$ & $V_{\mathrm{oc}}(\mathrm{V})$ & $V_{\mathrm{m}}(\mathrm{V})$ & $\mathrm{FF}(\%)$ & \multicolumn{1}{c}{$\eta(\%)$} \\
\hline Spinach & 0.41 & 0.309 & 0.59 & 0.46 & 58.75982 & 0.171253 \\
Onion & 0.24 & 0.158 & 0.48 & 0.34 & 46.63194 & 0.064723 \\
Red cabbage & 0.21 & 0.156 & 0.51 & 0.32 & 46.61064 & 0.060145 \\
\hline
\end{tabular}

TABLe 4: Photoelectrochemical parameters of the DSSCs with spinach extract over a week.

\begin{tabular}{lcccccc}
\hline Days & $J_{\mathrm{sc}}\left(\mathrm{mA} \cdot \mathrm{cm}^{-2}\right)$ & $J_{\mathrm{m}}\left(\mathrm{mA} \cdot \mathrm{cm}^{-2}\right)$ & $V_{\mathrm{oc}}(\mathrm{V})$ & $V_{\mathrm{m}}(\mathrm{V})$ & $\mathrm{FF}(\%)$ & \\
\hline 1 & 0.41 & 0.309 & 0.59 & 0.46 & 58.75982 \\
2 & 0.37 & 0.286 & 0.56 & 0.44 & 60.73359 \\
3 & 0.29 & 0.198 & 0.57 & 0.44 & 52.70417 & 0.151614 \\
7 & 0.26 & 0.181 & 0.55 & 0.38 & 48.0979 & 0.104964 \\
\hline
\end{tabular}

and yields pigment solutions with large amounts of byproducts such as sugars, sugar alcohols, organic acids, amino acids, and proteins [44]. These impurities cause the acceleration of anthocyanin degradation during storage. For spinach, the dyes extracted contains mainly chlorophyll and carotenoids (xanthophyll and carotene). Xanthophyll contains oxygen atoms, most frequently as hydroxyl and epoxide groups, which increase their polarity and are useful for the bindings on the $\mathrm{TiO}_{2}$ layer [45]. For this reason, the spinach extract presented a considerably large PCE of $0.17 \%$, compared to $0.0647 \%$ and $0.060 \%$ for onion and red cabbage extracts, respectively. Spinach has the highest efficiency which is reasonable in comparison with its lifetime. These results are in agreement with the previously reported reports [22]. The photoelectrochemical parameters of the sensitized cell with spinach extract for a week are presented in Table 4.

The interfacial kinetics and reactions of DSSC were investigated under dark conditions at $0 \mathrm{~V}$ by measuring the electrochemical impedance spectroscopy (EIS). The results of EIS are shown in Figure 7. Normally, the Nyquist plot of DSSC exhibits three frequency regions. The high-frequency region can be attributed to the charge transfer resistance at Pt/electrolyte interface. The middle-frequency region corresponds to the charge transfer recombination resistance at $\mathrm{TiO}_{2} /$ dye/electrolyte interface. The low-frequency region is assigned to Warburg resistance and the diffusion properties of the redox couple $\left(\mathrm{I}_{3}^{-} / \mathrm{I}^{-}\right)$in the electrolyte. The Nyquist plots of different dyes were fitted using a suitable circuit as shown in Figure 7 . The big semicircles in the middlefrequency region indicated low charge recombination at the $\mathrm{TiO}_{2} /$ dye/electrolyte interface. Natural dyes anchored to $\mathrm{TiO}_{2}$ showed a larger impedance compared to N719, which explains the higher performance of DSSC based on N719 compared to the extracted dyes. The DSSCs based on onion peel dye showed higher resistance to recombination than the other dyes. Larger radius indicated slower charge recombination rate [46].

Table 5 summarizes the fitting results. $R_{1}$ is the series resistance, $R_{2}$ is the resistance of electron transport in the counter electrode, and $R_{3}$ is the electron transfer resistance between the $\mathrm{TiO}_{2}$ film and electrolyte. The charge transfer

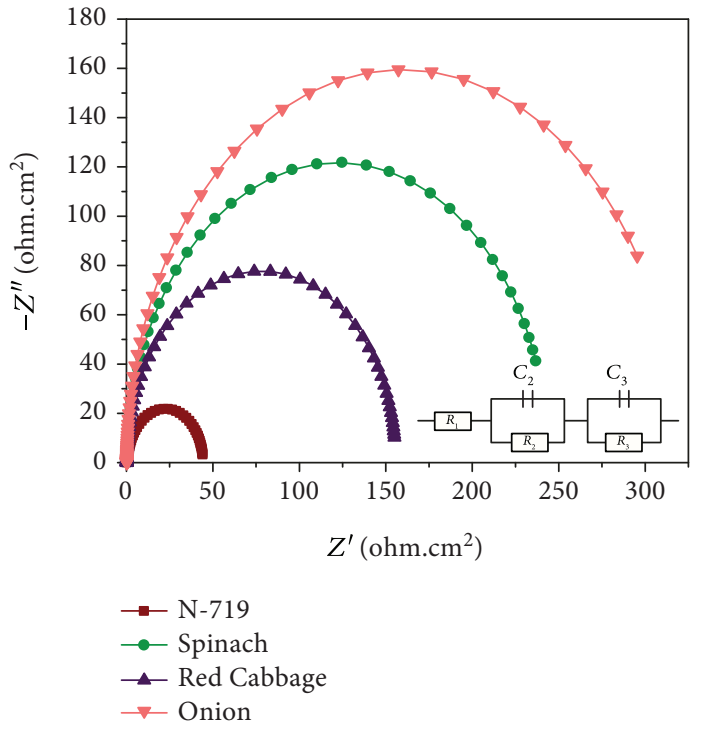

FIGURE 7: Electrochemical impedance spectra of DSSCs based on natural sensitizers and N719.

resistances for N719, spinach, onion, and red cabbage were $79.76,126.3,371.3$, and $430.6 \Omega$, respectively. The increase in charge transfer resistance refers to higher degradation and detachment rate [40,47] which is in consistent with the cell efficiencies shown in Figures 3 and 6. Furthermore, it can be concluded that spinach dye shows high efficiency due to its longer charge carrier lifetime (20.98 ms, Table 5). The long lifetime implies a lower recombination rate and enhanced electron collection efficiency [48]. Accordingly, it is expected for spinach-based DSSC to obtain higher efficiency than N719. However, this is not the case, very likely due to the favorable bonding conditions of N719 complex with $\mathrm{TiO}_{2}$ compared to the natural dyes [49].

\section{Conclusions}

The extraction, preparation, and photovoltaic performance of DSSCs based on natural sensitizers and N719 were 
TABLE 5: Electrochemical impedance parameters of DSSCs based on different dye sensitizers.

\begin{tabular}{lccccc}
\hline Dye & $R_{1}(\mathrm{ohm})$ & $R_{2}(\mathrm{ohm})$ & $R_{3}(\mathrm{ohm})$ & $F_{\max }(\mathrm{Hz})$ & $\tau_{\mathrm{n}}(\mathrm{ms})$ \\
\hline N719 & 22.17 & 4.343 & 79.76 & 17.498 & 9.095 \\
Spinach & 27.53 & 48.452 & 126.3 & 7.586 & 20.98 \\
Onion & 25.57 & 60.445 & 371.3 & 30.98 & 5.137 \\
Red cabbage & 25.41 & 16.021 & 430.6 & 35.48 & 4.486 \\
\hline
\end{tabular}

optimized. Natural dyes can be easily and safely extracted by simple techniques. The UV-visible absorption and photoluminescence properties of the extracted dyes were studied. Among the dyes extracted, chlorophyll gave the longest lifetime and the highest possible efficiency. The DSSCs prepared with a photoelectrode thin film of $10 \% \mathrm{TiO}_{2}$ showed the highest photoelectric conversion efficiency of $2.239 \%$. The DSSC based on chlorophyll dye showed the highest performance among the natural extracted dyes with power conversion efficiency of $0.17 \%$.

\section{Data Availability}

All data generated or analyzed during this study are included in the submitted article.

\section{Conflicts of Interest}

The authors declare no conflicts of interest regarding the publication of this paper.

\section{Acknowledgments}

This work was partially supported by the Egyptian Ministry of Higher Education (STDF and ASRT).

\section{Supplementary Materials}

SI 1: $J$ - $V$ curves of (A) spinach-based DSSC and (B) N719based DSSC after extended operation time and electrolyte reloading. SI 2: performance of spinach-based DSSC after extended operation time and electrolyte reloading. SI 3: performance of N719-based DSSC after extended operation time and electrolyte reloading. (Supplementary Materials)

\section{References}

[1] C. Dang, R. Labie, E. Simoen, and J. Poortmans, "Detailed structural and electrical characterization of plated crystalline silicon solar cells," Solar Energy Materials and Solar Cells, vol. 184, pp. 57-66, 2018.

[2] F. Schindler, A. Fell, R. Müller et al., "Towards the efficiency limits of multicrystalline silicon solar cells," Solar Energy Materials and Solar Cells, vol. 185, pp. 198-204, 2018.

[3] M. Stuckelberger, R. Biron, N. Wyrsch, F. J. Haug, and C. Ballif, "Review: progress in solar cells from hydrogenated amorphous silicon," Renewable and Sustainable Energy Reviews, vol. 76, pp. 1497-1523, 2017.
[4] F. Alta and E. S. Asu, "National Renewable Energy Labs (NREL) efficiency chart,” 2019, p. 2020, http://www.nrel.gov/ pv/cell-efficiency.html.

[5] B. O'Regan and M. Grätzel, "A low-cost, high-efficiency solar cell based on dye-sensitized colloidal $\mathrm{TiO}_{2}$ films," Nature, vol. 353, no. 6346, pp. 737-740, 1991.

[6] J. Zhang, H. S. Tan, X. Guo, A. Facchetti, and H. Yan, "Material insights and challenges for non-fullerene organic solar cells based on small molecular acceptors," Nature Energy, vol. 3, no. 9, pp. 720-731, 2018.

[7] Y. Chiba, A. Islam, Y. Watanabe, R. Komiya, N. Koide, and L. Han, "Dye-sensitized solar cells with conversion efficiency of 11.1\%," Japanese Journal of Applied Physics, vol. 45, no. 25, pp. L638-L640, 2006.

[8] R. Buscaino, C. Baiocchi, C. Barolo et al., "A mass spectrometric analysis of sensitizer solution used for dye-sensitized solar cell," Inorganica Chimica Acta, vol. 361, no. 3, pp. 798-805, 2008.

[9] M. K. Kashif, M. Nippe, N. W. Duffy et al., "Stable dyesensitized solar cell electrolytes based on cobalt(ii)/(iii) complexes of a hexadentate pyridyl ligand," Angewandte Chemie International Edition, vol. 52, no. 21, pp. 5527-5531, 2013.

[10] S. Sarwar, K. W. Ko, J. Han, C. H. Han, Y. Jun, and S. Hong, "Improved long-term stability of dye-sensitized solar cell by zeolite additive in electrolyte," Electrochimica Acta, vol. 245, pp. 526-530, 2017.

[11] M. Lv, D. Zheng, M. Ye et al., "Optimized porous rutile $\mathrm{TiO}_{2}$ nanorod arrays for enhancing the efficiency of dye-sensitized solar cells," Energy \& Environmental Science, vol. 6, no. 5, p. 1615, 2013.

[12] H. Zhang, Y. Wang, D. Yang et al., "Directly hydrothermal growth of single crystal $\mathrm{Nb3} \mathrm{O} 7(\mathrm{OH})$ nanorod film for high performance dye-sensitized solar cells," Advanced Materials, vol. 24, no. 12, pp. 1598-1603, 2012.

[13] M. Ye, D. Zheng, M. Lv, C. Chen, C. Lin, and Z. Lin, "Hierarchically structured nanotubes for highly efficient dyesensitized solar cells," Advanced Materials, vol. 25, no. 22, pp. 3039-3044, 2013.

[14] Y. Shi, C. Zhu, L. Wang, W. Li, K. K. Fung, and N. Wang, "Asymmetric ZnO panel-like hierarchical architectures with highly interconnected pathways for free-electron transport and photovoltaic improvements," Chemistry - A European Journal, vol. 19, no. 1, pp. 282-287, 2013.

[15] K.-N. Li, Y. F. Wang, Y. F. Xu, H. Y. Chen, C. Y. Su, and D. B. Kuang, "Macroporous $\mathrm{SnO}_{2}$ synthesized via a templateassisted reflux process for efficient dye-sensitized solar cells," ACS Applied Materials \& Interfaces, vol. 5, no. 11, pp. 51055111, 2013.

[16] Y. Huang, W. C. Chen, R. Ghadari et al., "Highly efficient ruthenium complexes with acetyl electron-acceptor unit for dye sensitized solar cells," Journal of Power Sources, vol. 396, pp. 559-565, 2018.

[17] K. L. Wu, S. T. Ho, C. C. Chou et al., "Engineering of osmium(II)-based light absorbers for dye-sensitized solar cells," Angewandte Chemie International Edition, vol. 51, no. 23, pp. 5642-5646, 2012.

[18] J. Leyrer, M. Rubilar, E. Morales, B. Pavez, E. Leal, and R. Hunter, "Factor optimization in the manufacturing process of dye-sensitized solar cells based on naturally extracted dye from a Maqui and blackberry mixture (Aristotelia chilensis 
and Rubus glaucus)," Journal of Electronic Materials, vol. 47, no. 10 , pp. 6136-6143, 2018.

[19] G. Calogero, J. Barichello, I. Citro et al., "Photoelectrochemical and spectrophotometric studies on dye-sensitized solar cells (DSCs) and stable modules (DSCMs) based on natural apocarotenoids pigments," Dyes and Pigments, vol. 155, pp. 75-83, 2018.

[20] E. C. Prima, A. Nuruddin, B. Yuliarto, G. Kawamura, and A. Matsuda, "Combined spectroscopic and TDDFT study of single-double anthocyanins for application in dye-sensitized solar cells," New Journal of Chemistry, vol. 42, no. 14, pp. 11616-11628, 2018.

[21] S. Hao, J. Wu, Y. Huang, and J. Lin, "Natural dyes as photosensitizers for dye-sensitized solar cell," Solar Energy, vol. 80, no. 2, pp. 209-214, 2006.

[22] H. Chang, H. M. Wu, T. L. Chen, K. D. Huang, C. S. Jwo, and Y. J. Lo, "Dye-sensitized solar cell using natural dyes extracted from spinach and ipomoea," Journal of Alloys and Compounds, vol. 495, no. 2, pp. 606-610, 2010.

[23] G. R. A. Kumara, S. Kaneko, M. Okuya, B. Onwona-Agyeman, A. Konno, and K. Tennakone, "Shiso leaf pigments for dyesensitized solid-state solar cell," Solar Energy Materials \& Solar Cells, vol. 90, no. 9, pp. 1220-1226, 2006.

[24] E. Yamazaki, M. Murayama, N. Nishikawa, N. Hashimoto, M. Shoyama, and O. Kurita, "Utilization of natural carotenoids as photosensitizers for dye-sensitized solar cells," Solar Energy, vol. 81, no. 4, pp. 512-516, 2007.

[25] N. M. Gómez-Ortíz, I. A. Vázquez-Maldonado, A. R. PérezEspadas, G. J. Mena-Rejón, J. A. Azamar-Barrios, and G. Oskam, "Dye-sensitized solar cells with natural dyes extracted from achiote seeds," Solar Energy Materials \& Solar Cells, vol. 94, no. 1, pp. 40-44, 2010.

[26] P. M. Sirimanne, M. K. I. Senevirathna, E. V. A. Premalal, P. K. D. D. P. Pitigala, V. Sivakumar, and K. Tennakone, "Utilization of natural pigment extracted from pomegranate fruits as sensitizer in solid-state solar cells," Journal of Photochemistry and Photobiology A: Chemistry, vol. 177, no. 2-3, pp. 324327, 2006.

[27] K. Wongcharee, V. Meeyoo, and S. Chavadej, “Dye-sensitized solar cell using natural dyes extracted from rosella and blue pea flowers," Solar Energy Materials \& Solar Cells, vol. 91, no. 7, pp. 566-571, 2007.

[28] G. Calogero and G. Di Marco, "Red Sicilian orange and purple eggplant fruits as natural sensitizers for dye-sensitized solar cells," Solar Energy Materials and Solar Cells, vol. 92, no. 11, pp. 1341-1346, 2008.

[29] Q. Dai and J. Rabani, "Photosensitization of nanocrystalline $\mathrm{TiO}_{2}$ films by anthocyanin dyes," Journal of Photochemistry and Photobiology A: Chemistry, vol. 148, no. 1-3, pp. 17-24, 2002.

[30] N. J. Cherepy, G. P. Smestad, M. Grätzel, and J. Z. Zhang, "Ultrafast electron injection: implications for a photoelectrochemical cell utilizing an anthocyanin dye-sensitized $\mathrm{TiO}_{2}$ nanocrystalline electrode," The Journal of Physical Chemistry $B$, vol. 101, no. 45, pp. 9342-9351, 1997.

[31] S. Furukawa, H. Iino, T. Iwamoto, K. Kukita, and S. Yamauchi, "Characteristics of dye-sensitized solar cells using natural dye," Thin Solid Films, vol. 518, no. 2, pp. 526-529, 2009.

[32] M. Özbay Karakuş, İ. Koca, O. Er, and H. Çetin, "Dye ingredients and energy conversion efficiency at natural dye sensitized solar cells," Optical Materials, vol. 66, pp. 552-558, 2017.
[33] R. Ramanarayanan, P. Nijisha, C. V. Niveditha, and S. Sindhu, "Natural dyes from red amaranth leaves as light-harvesting pigments for dye-sensitized solar cells," Materials Research Bulletin, vol. 90, pp. 156-161, 2017.

[34] M. Hosseinnezhad, R. Jafari, and K. Gharanjig, "Characterization of a green and environmentally friendly sensitizer for a low cost dye-sensitized solar cell," Opto-Electronics Review, vol. 25, no. 2, pp. 93-98, 2017.

[35] D. Joly, L. Pellejà, S. Narbey et al., “A robust organic dye for dye sensitized solar cells based on iodine/iodide electrolytes combining high efficiency and outstanding stability," Scientific Reports, vol. 4, no. 1, article 4033, 2015.

[36] O. Adedokun, Y. K. Sanusi, and A. O. Awodugba, "Solvent dependent natural dye extraction and its sensitization effect for dye sensitized solar cells," Optik, vol. 174, pp. 497-507, 2018.

[37] R. S. Ganesh, M. Navaneethan, S. Ponnusamy et al., "Enhanced photon collection of high surface area carbonatedoped mesoporous $\mathrm{TiO}_{2}$ nanospheres in dye sensitized solar cells," Materials Research Bulletin, vol. 101, pp. 353-362, 2018.

[38] D. K. Hwang, B. Lee, and D. H. Kim, "Efficiency enhancement in solid dye-sensitized solar cell by three-dimensional photonic crystal," RSC Advances, vol. 3, no. 9, pp. 3017-3023, 2013.

[39] H. Tributsch, "Dye sensitization solar cells: a critical assessment of the learning curve," Coordination Chemistry Reviews, vol. 248, no. 13-14, pp. 1511-1530, 2004.

[40] M. Lohrasbi, P. Pattanapanishsawat, M. Isenberg, and S. S. C. Chuang, "Degradation study of dye-sensitized solar cells by electrochemical impedance and FTIR spectroscopy," in 2013 IEEE Energytech, pp. 1-4, USA, July 2013.

[41] H. Chang, M. J. Kao, T. L. Chen, C. H. Chen, K. C. Cho, and X. R. Lai, "Characterization of natural dye extracted from wormwood and purple cabbage for dye-sensitized solar cells," International Journal of Photoenergy, vol. 2013, Article ID 159502, 8 pages, 2013.

[42] D. Ganta, J. Jara, and R. Villanueva, "Dye-sensitized solar cells using aloe vera and cladode of cactus extracts as natural sensitizers," Chemical Physics Letters, vol. 679, pp. 97-101, 2017.

[43] R. Kushwaha, P. Srivastava, and L. Bahadur, "Natural pigments from plants used as sensitizers for $\mathrm{TiO}_{2}$ based dyesensitized solar cells," Journal of Energy, vol. 2013, Article ID 654953, 8 pages, 2013.

[44] J. Chandrasekhar, M. C. Madhusudhan, and K. S. M. S. Raghavarao, "Extraction of anthocyanins from red cabbage and purification using adsorption," Food and Bioproducts Processing, vol. 90, no. 4, pp. 615-623, 2012.

[45] M. Rossi, F. Matteocci, A. Di Carlo, and C. Forni, "Chlorophylls and xanthophylls of crop plants as dyes for dyesensitized solar cells (DSSC)," Journal of Plant Science and Phytopathology, vol. 1, no. 2, pp. 087-094, 2017.

[46] L. Wei, Y. Yang, Z. Zhu et al., "Effect of different donor groups in bis(6-methoxylpyridin-2-yl) substituted co-sensitizer on the performance of N719 sensitized solar cells," RSC Advances, vol. 5, no. 117, pp. 96934-96944, 2015.

[47] B. Macht, M. Turrión, A. Barkschat, P. Salvador, K. Ellmer, and H. Tributsch, "Patterns of efficiency and degradation in dye sensitization solar cells measured with imaging techniques," Solar Energy Materials and Solar Cells, vol. 73, no. 2, pp. 163-173, 2002. 
[48] D. Maheswari and P. Venkatachalam, "Performance enhancement in dye-sensitized solar cells with composite mixtures of $\mathrm{TiO}_{2}$ nanoparticles and $\mathrm{TiO}_{2}$ nanotubes," Acta Metallurgica Sinica (English Letters), vol. 28, no. 3, pp. 354-361, 2015.

[49] H. J. Ahn, S. Thogiti, J. M. Cho, B. Y. Jang, and J. H. Kim, "Comparison of triphenylamine based single and double branched organic dyes in dye-sensitized solar cells," Electronic Materials Letters, vol. 11, no. 5, pp. 822-827, 2015. 


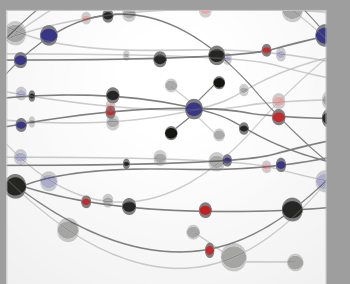

The Scientific World Journal
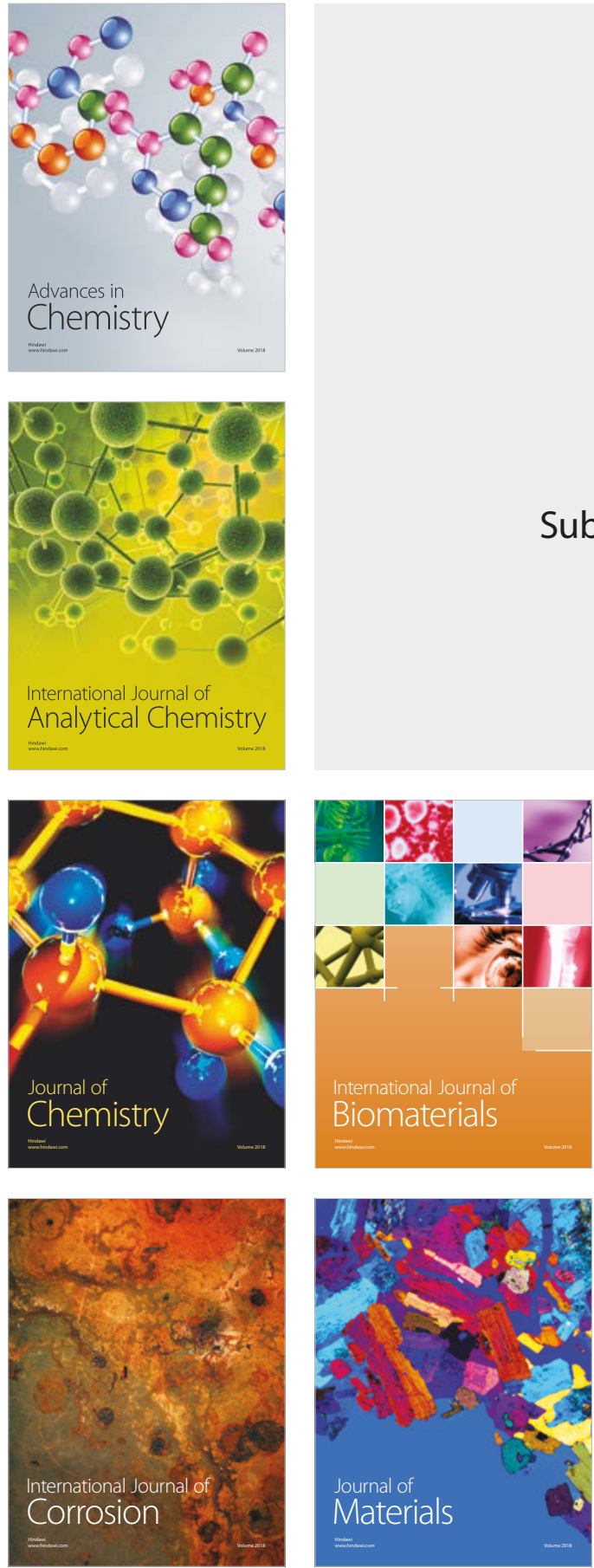

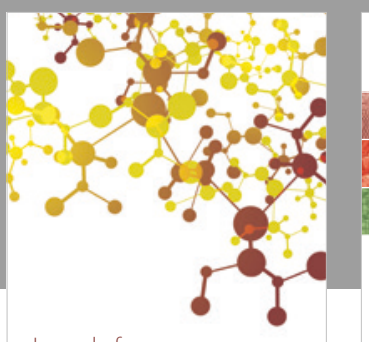

Journal of

Applied Chemistry
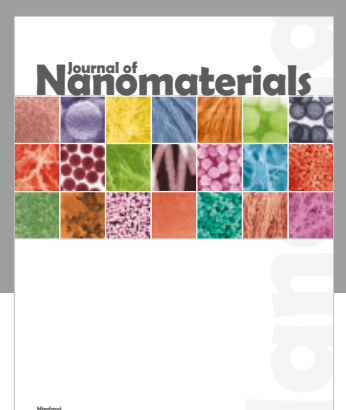

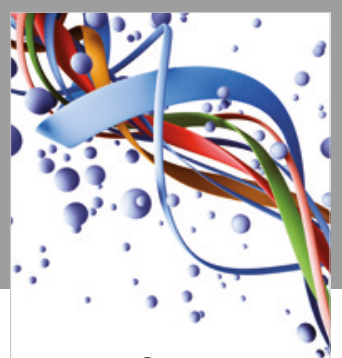

Scientifica

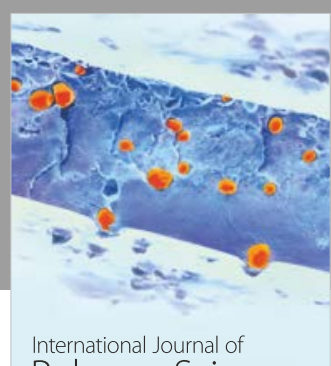

Polymer Science

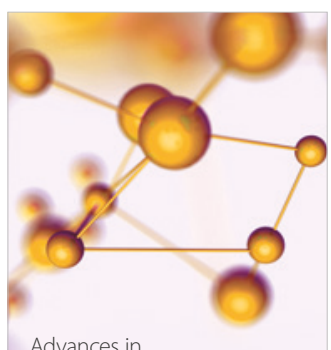

Physical Chemistry
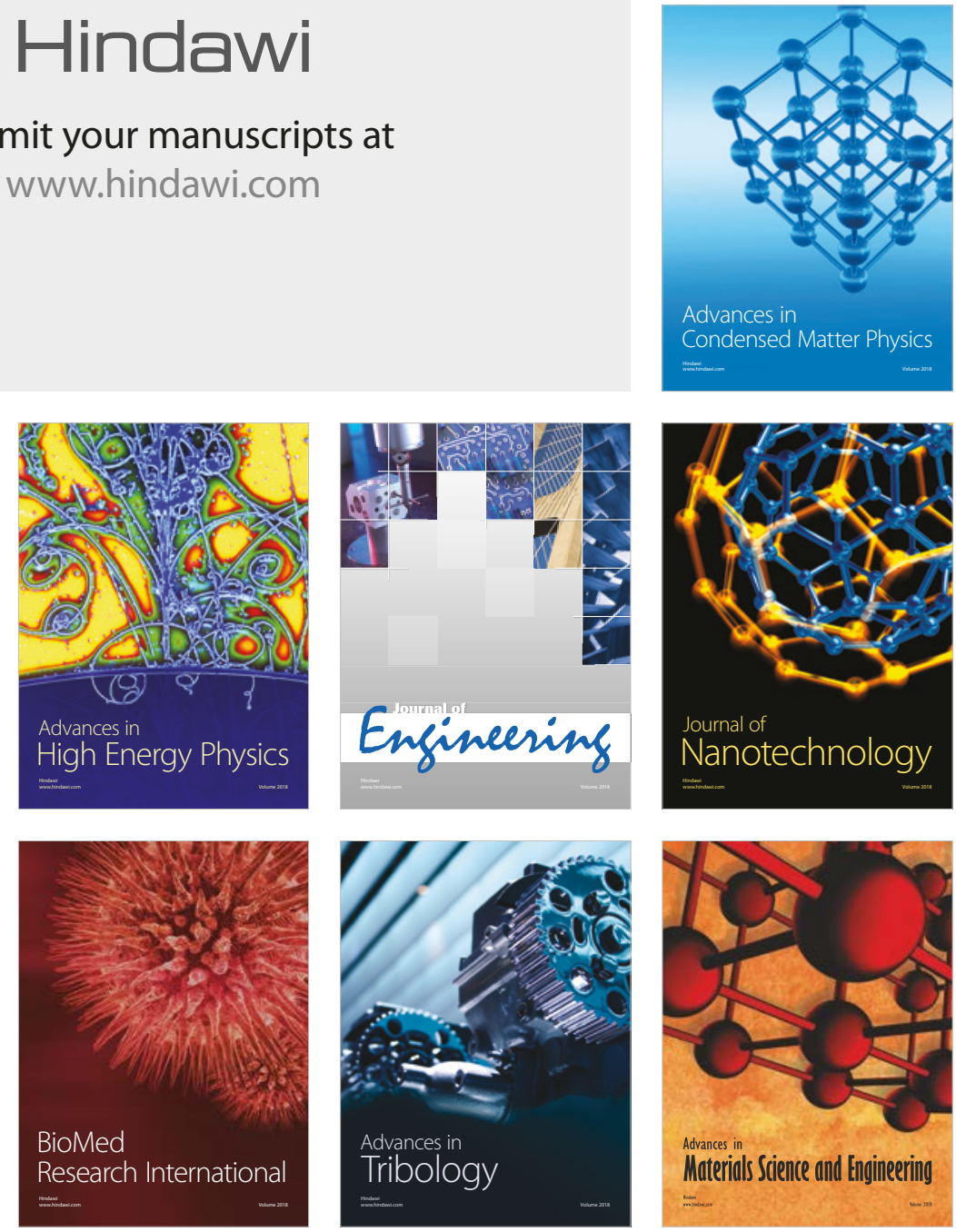